Diet may play a role in both promoting and inhibiting human breast cancer development. In this review, nutritional risk factors such as consumption of dietary fat, meat, fiber, and alcohol, and intake of phytoestrogen, vitamin D, iron, and folate associated with breast cancer are reviewed. These nutritional factors have a variety of associations with breast cancer risk. Type of fat consumed has different effects on risk of breast cancer: consumption of meat is associated with heterocyclic amine (HCA) exposure; different types of plant fiber have various effects on breast cancer risk; alcohol consumption may increase the risk of breast cancer by producing acetaldehyde and reactive oxygen species (ROS); intake of phytoestrogen may reduce risk of breast cancer through genomic and non-genomic action; vitamin D can reduce the risk of breast cancer by inhibiting the process of cancer invasion and metastasis; intake of dietary iron may lead to oxidative stress, DNA damage, and lipid peroxidation; and lower intake of folate may be linked to a higher risk of breast cancer.

Key words: diet, nutrition, mechanism, breast cancer.

Contemp Oncol (Pozn) 2014; 18: 1-7 DOI: $10.5114 /$ wo. 2014.40560

\section{Diet and risk of breast cancer}

\author{
Manas Kotepui
}

Medical Technology Program, School of Allied Health Sciences and Public Health, Walailak University, Thailand

\section{Introduction}

Breast cancer is the most common cancer among women worldwide and the incidence has continued to rise over time [1]. Nutrition influences cancer etiology in about $35 \%$ of cancer cases [2]. Preventive dietary advice often includes reducing intake of alcohol, red meat, and fat and increasing intake of fiber and vitamin D as well as phytoestrogens from various food sources. The mechanisms of dietary risk factors are not entirely understood. This review aims to describe potential nutritional risk factors of dietary components associated with breast cancer as well as the proposed mechanism of each risk factor.

\section{Dietary fat and breast cancer \\ Epidemiological studies}

Epidemiological studies have reported conflicting results regarding the association of dietary fat with breast cancer risk. Diets high in polyunsaturated fat have been reported to increase the occurrence of mammary tumors in animal models [3]. One case-control study indicated a weak association [4], and prospective cohort studies and a meta-analysis have also shown weak $[5,6]$ or no association [7-10]. Other studies have explored the association of consumption of different types of fat on breast cancer risk. A large cohort study ( $n=49261)$ reported no association between intake of total fat, monounsaturated fatty acids, polyunsaturated fatty acids (PUFA), or saturated fatty acids (SFA) and risk of breast cancer [10]. A prospective investigation of fat consumption in a larger population $(n=319826)$ indicated a weak positive association between intake of SFA and breast cancer risk [11]. These findings suggest that different types of fat may have different effects on breast cancer risk. A recent study reported that intake of myristoleic, erucic acids, palmitic, margaric, linoleic acid, and stearic acids is associated with an increased risk of breast cancer while intake of trans-fatty acids and PUFA was not associated with risk of breast cancer [12]. Fat from different types of food may have different effects on risk of breast cancer. For example, intake of alpha-linolenic acid (ALA) from fruit and vegetable oils is inversely associated with risk of breast cancer. Conversely, intake of ALA from nut mixes and processed foods is positively related to risk of breast cancer [12]. PUFA from fish such as eicosapentaenoic (EPA) and docosahexaenoic acids (DHA) have been shown to be inversely associated with risk of breast cancer [13]. One study suggested that relative amounts of n-6 PUFA such as linoleic acid to marine-derived n-3 PUFA such as ALA, EPA, and DHA may be more important to breast cancer risk than individual dietary amounts of these fatty acids. Low intake of marine-derived n-3 PUFA and high intake of n- 6 PUFA have been reported to increase risk of breast cancer [14].

\section{Mechanism}

There are several mechanisms proposed to explain the association of fat intake with breast cancer risk. High fat intake leads to accumulation of adipose tissue, which is an important site for the conversion of androstene- 
dione to estrone. Arachidonic acid, a metabolite of PUFA, activates P450 aromatase that then increases conversion of androstenedione to estrone. PUFA can reduce the binding of estrogens to serum binding proteins, including both sex-hormone binding globulin (SHBG) and albumin, thereby increasing the circulating levels of the biologically potent estrogens which may activate breast cell growth [15]. EPA and DHA have been found to inhibit the production of arachidonic acid-derived eicosanoids in tumors [16]. Lipid peroxidation of fat can induce apoptosis $[17,18]$. n-3 PUFA can bind and activate peroxisome proliferator-activated receptor gamma (PPAR), leading to activation of the proteoglycan syndecan-1 in human breast cancer cells, promoting apoptosis leading to cell growth inhibition [19]. Linoleic acid can generate 13-hydroxylinoleic acid (13-HODE), which enhances the growth stimulating signal of peptide growth factors such as epidermal growth factor (EGF) and insulin, which can in turn promote the growth of cancer cells [18].

\section{Meat consumption and breast cancer}

\section{Epidemiological studies}

Several studies have investigated the association between intake of meat cooked at high temperatures and HCA exposure and risk of breast cancer [20-27]. Some reported no association [22, 23] while others reported positive associations [20, 21, 24-26]. One study found that women who had a consistent intake of well-done meat had a 4.6-fold (95\% Cl: 1.4-15.7) elevated risk of breast cancer [21]. In a large prospective cohort of the Black Women's Health Study $(n=52$ 062), no association was observed between total meat intake and risk of breast cancer [23]. In a larger cohort study $(n=61433)$, no association between intake of total red meat, fresh red meat, or processed meat and risk of breast cancer was observed when high total red meat intake $(98 \mathrm{~g} / \mathrm{d})$ was compared to low total red meat intake ( $<46 \mathrm{~g} / \mathrm{d}$ ) [24]. Among women who eat red meat, a higher risk of breast cancer was observed in those who were postmenopausal than those who were premenopausal [26]. A possible explanation for the inconsistency between meat intake and breast cancer risk is that these associations differ according to type of meat consumed, cooking method, and degree of doneness [27]. The amount of meat-derived mutagens, such as heterocyclic amines (HCAs) and polycyclic aromatic hydrocarbons (PAHs), is related to methods of cooking as well as cooking temperatures and duration. These mutagens have been shown to induce mammary gland tumors in animal models [28-30].

\section{Mechanism}

The mechanism proposed to explain the association between meat consumption and risk of breast cancer is the metabolic activation of HCAs involving the cytochrome P450-mediated $\mathrm{N}$-hydroxylation in liver and transportation of HCA metabolites to the breast, where high $\mathrm{N}$-acetyl transferase activity makes HCAs most reactive. These highly reactive metabolites then bind to DNA where DNA adducts are generated. These DNA adducts can induce genetic mutations which result in mammary gland carcinogenesis [31]. Several studies have also suggested that intake of well-done meat and risk of breast cancer may be associated with genetic polymorphisms such as those of NAT1, NAT2, GSTM1, GSTT1, and SULT1A1 genes which encode enzymes for HCA activation or detoxification [25, 32-35].

\section{Dietary fiber and breast cancer}

\section{Epidemiological studies}

The protective effect of dietary fiber on breast cancer risk is currently inconclusive. Several prospective cohort studies have examined the association between dietary fiber intake and risk of breast cancer and found inconclusive results [36-38], with mostly weak or no association. Recently, several studies have observed a significant inverse association between dietary fiber intake and risk of breast cancer [39-44]. A meta-analysis of large prospective cohort studies ( $n=16848$ ) showed that high dietary fiber intake is a protective factor for breast cancer ( $R R=$ = 0.89; 95\% Cl: 0.83-0.96) compared with low intake; every $10-\mathrm{g} / \mathrm{d}$ incremental increase in dietary fiber intake was associated with a $7 \%$ reduction in risk of breast cancer [42]. Dietary fiber from different sources of food has been shown to have different protective effects. One study reported that increasing intake of berries and peaches by 1-2 servings/week is a protective factor compared with no consumption of the same foods [43]. As another example, high dietary intake of plant lignans and enterolignans, but not lariciresinol, is associated with reduced risk of breast cancer [44].

\section{Mechanism}

More than one mechanism explaining the role of fiber in lowering risk of breast cancer has been proposed [45, 46]. A high fiber diet can increase the excretion of estrogens and decrease plasma estradiol concentrations and high fecal fiber can inhibit absorption of estrogens in the gut, thereby reducing the total body pool of estrogen. Another proposed mechanism is the binding of unconjugated estrogens to fiber in the gut, thereby decreasing estrogen reabsorption [45]. Disturbance of the enterohepatic circulation of cholesterol, a precursor of estrogens, may also reduce the risk of breast cancer [46].

\section{Alcohol consumption and breast cancer}

\section{Epidemiological studies}

Epidemiological studies have consistently found that alcohol consumption can increase the risk of breast cancer. Among women who consume alcohol regularly, an increase in alcohol consumption may potentially increase breast cancer risk [47-49]. In addition, alcohol consumption over the recommended amount is associated with a linear increase in incidence of breast cancer [50]. Risk depends upon the amount of alcohol consumed; relative risk of breast cancer has been shown to increase by $7.1 \%$ (95\% Cl: 5.5-8.7\%; $p<0.00001$ ) for each additional $10 \mathrm{~g}$ per day intake of alcohol [51]. Inconsistencies in some studies 
of the association between alcohol consumption and risk of breast cancer are thought to be due to the low magnitude of association, low consumption patterns, and under reporting of alcohol consumption [52].

\section{Mechanism}

Several mechanisms explaining the association of alcohol consumption and risk of breast cancer have been proposed. Alcohol may affect breast cancer risk by increasing levels of intracellular estrogens which act through the estrogen receptors (ER) to promote breast tumor growth [53]. Among premenopausal women, moderate intake of alcohol can decrease menstrual cycle variability and increase frequency of long menstrual cycles, thereby increasing exposure to endogenous estrogens [49]. The metabolism of alcohol can produce acetaldehyde and other reactive oxygen species (ROS) which are known to induce DNA modifications, by generating protein adducts, chromosomal aberrations, and DNA point mutations [53-56]. Alcohol can also inhibit absorption of folate and therefore interfere with the DNA repair mechanism [48].

\section{Phytoestrogens and breast cancer}

\section{Epidemiological studies}

Phytoestrogens are plant substances which are categorized into three classes according to their structure: isoflavones, coumestans, and lignans. Most researchers are interested in isoflavones, present mostly in soybean and soy products, because their structures are similar to mammalian estrogens [57]. A meta-analysis of observational studies reported that intake of isoflavones may be associated with reduced risk of breast cancer $[58,59]$. Reduced risk of breast cancer was found especially in postmenopausal women and Asian populations but not in Western populations, which may be due to the low intake of isoflavones in Western countries [58-60]. The risk of breast cancer significantly decreased in women with high intake of flavonols and flavones while no significant association of flavan-3-ols, flavanones, anthocyanins, or total flavonoids intake and risk of breast cancer was observed [61].

\section{Mechanism}

Phytoestrogens can act as estrogen agonists and antagonists known as selective estrogen receptor modulators (SERMs) [62]. SERMs are non-steroidal chemicals with a similar structure to estrogen and an affinity toward ER [63] depending on the tissue, ER, and concentration of circulating endogenous estrogens [64]. Phytoestrogen activity can act though both genomic and non-genomic mechanisms [65]. By genomic action, it can pass through cell membranes to interact with enzymes and receptors [66]. Isoflavones can competitively bind to ER, blocking estrogens from binding to their receptor [57]. The opposite mechanism, binding to ER, induces estrogen-responsive gene products which can stimulate ER-positive breast cancer cell growth. By non-genomic action, phytoestrogen can induce differentiation of cancer cells, inhibit tyrosine kinase and activities of DNA topoisomerase, and suppress angiogenesis [67]. Moreover, isoflavones and flavonoids are the most potent inhibitors of aromatase, the enzyme that converts androgens to estrogens [68].

\section{Vitamin D and breast cancer}

\section{Epidemiological studies}

It has been hypothesized that vitamin D can reduce the risk of breast cancer. Several studies have examined the effects of vitamin D on mammary carcinogenesis in cell lines and animal models and found a protective role of vitamin D in breast cancer development [69-71]. A high concentration of plasma $25(\mathrm{OH}) \mathrm{D}$ is associated with a significantly reduced risk of premenopausal breast cancer [72]. Reduction in risk of breast cancer depends on the amount of vitamin D. A serum 25-hydroxyvitamin D (25(OH)D) level of $50 \mathrm{ng} / \mathrm{ml}$ was associated with $50 \%$ lower incidence of breast cancer, compared to a baseline of $<10 \mathrm{ng} / \mathrm{ml}$ [73]. Every $1 \mathrm{ng} / \mathrm{ml}$ increment of plasma 25(OH)D level can decrease breast cancer risk by $16 \%$ [74]. Some studies have not supported the role of vitamin $D$ in the development of breast cancer $[75,76]$. In a large prospective cohort ( $n=319$ 985), no association between intake of dietary vitamin D and risk of breast cancer was observed [77]. The relationship of vitamin $D$ with risk of breast cancer may be subtype-specific, with evidence of stronger effects of vitamin $D$ for more aggressive breast cancer, especially in African women [78]. Many epidemiological studies have reported positive associations between gene polymorphisms and risk of breast cancer; these include vitamin D related genes such as Fok1 [79] and Bsm1 [80], and vitamin D-binding protein genes such as rs4588 and rs7041 [81], as well as the CYP24A1 gene [78].

\section{Mechanism}

The mechanism associated with reduction in risk of breast cancer related to vitamin $\mathrm{D}$ intake is the growth arrest and apoptosis such as 1,25(OH)2D and cell-cycle arrest caused by increasing the expression of cyclin-dependent kinase inhibitors such as p21 and p27 [82, 83]. 1,25(OH)2D can also induce morphological changes associated with apoptosis in breast cancer cells [84]. Vitamin D can inhibit the invasion and metastasis of cancer cell 1,25(OH)2D and has potent anti-angiogenic properties that can inhibit tumor cell invasion [70], decrease the activity of matrix metalloproteinases (MMPs), and increase the expression of plasminogen activator inhibitors and MMP inhibitor 1 [71]. Vitamin D can act as an anti-inflammatory such that $1,25(\mathrm{OH}) 2 \mathrm{D}$ can down-regulate the expression of cyclooxygenase-2 (COX-2), which plays a role in prostaglandin synthesis in human breast cancer [85]. Vitamin D can also inhibit the estrogen pathway such that 1,25(OH)2D can reduce the expression of the aromatase gene, a gene encoding an enzyme that converts androgens to estrogens [85].

\section{Dietary iron and breast cancer}

\section{Epidemiological studies}

Some postmenopausal women appear to have high circulating iron concentrations because of high intake of 
meat, fortification of foods with iron, and the wide use of iron-containing dietary supplements [86, 87]. High levels of dietary iron have been linked epidemiologically to increased development of tumors in humans $[88,89]$ and animal models [90,91]. Studies have suggested that a low iron diet may lead to slow growth of tumors $[92,93]$.

\section{Mechanism}

High intake of dietary iron may lead to oxidative stress, DNA damage, and lipid peroxidation, which can increase the risk of breast cancer since iron has pro-oxidant properties [94-96]. Recently, a pathway that mediates iron efflux in breast cancer growth and metastasis was discovered [97]. This pathway is mediated by ferroportin and hepcidin. Ferroportin is an iron efflux pump and hepcidin is a peptide hormone that binds to ferroportin and triggers its degradation, leading to decreased export of cellular iron [98].

\section{Dietary folate and breast cancer}

\section{Epidemiological studies}

Results from previous studies on the association between intake of folate and risk of breast cancer have been inconsistent [32, 99-104]. One study found that folate intake was related to a decreased risk of breast cancer among premenopausal women [99] (Freudenheim et al. 1996), whereas other studies found an inverse association restricted to postmenopausal women [32, 102, 103, 105-107], especially those who drank alcohol regularly [108]. A more recent study revealed no overall association between intake of folate and risk of breast cancer, but a higher intake of folate was marginally associated with a lower risk for ER- breast cancer patients [104]. A large prospective cohort study ( $n=70656$ ) found that intake of folate was associated with a higher risk of breast cancer [106] and that women who consumed $\geq 1,272$ dietary folate equivalents (DFE)/day of total folate have a $22 \%$ decreased risk of breast cancer compared with women who consumed $\leq 345$ DFE/day [107].

\section{Mechanism}

Several studies have suggested that lower intake of folate may increase the risk of breast cancer by promoting the progression of pre-neoplastic lesions, expanding the breast stem cell population, or preventing terminal differentiation in ductal cells [109]. This promoting effect of folate on breast cancer development may be of particular importance among individuals who are predisposed to developing cancer, including women with high mammographic density, benign breast disease, a strong family history of breast cancer, or a BRCA1 or BRCA2 mutation. A family history of breast cancer is one of the strongest risk factors for breast cancer $[110,111]$. The lifetime risk depends on the number of relatives affected with breast cancer and their ages of diagnosis [110, 112]. The lifetime risks of breast cancer in these women are between 20 and 40\% and are significantly higher than risk levels in the general population [113].
In conclusion, the role of several dietary factors in breast cancer causation is not conclusively resolved. The evidence to date from epidemiologic studies suggests that diet may be associated with both increases and reductions of breast cancer risk, which may be related to the amount and type of foods consumed. Higher intake of foods containing n-3 PUFA, vitamin D, phytoestrogen, fiber, and folate, together with lower intake of saturated fat, n-6 PUFA, grilled meat, and alcohol, may be beneficial. However, additional investigations of the relationship between diet and breast cancer risk with well-designed epidemiological and laboratory studies should be conducted. Continued follow-up of patients with breast cancer to collect information on dietary intake and relevant biomarkers can be used to further investigate the potential benefits and risks related to diet as well as their mechanism of action in promoting breast cancer development.

The author declares no conflict of interest.

\section{References}

1. Ferlay J, Bray F, Forman D, Mathers C, Parkin DM. GLOBOCAN 2008 v1.2, Cancer Incidence and Mortality Worldwide: IARC Cancer Base No. 10. Lyon, France: International Agency for Research on Cancer, 2010.

2. Doll R, Peto R. The causes of cancer: quantitative estimates of avoidable risks of cancer in the United States today. J Natl Cancer Inst 1981; 66: 1191-308.

3. Holmes MD, Willett WC. Does diet affect breast cancer risk? Breast Cancer Res 2004; 6: 170-8.

4. Prentice RL, Kakar F, Hursting S, Sheppard L, Klein R, Kushi LH. Aspects of the rationale for the Women's Health Trial. J Natl Cancer Inst 1988; 80: 802-14.

5. Knekt P, Albanes D, Seppanen R, Aromaa A, Jarvinen R, Hyvonen L, Teppo L, Pukkala E. Dietary fat and risk of breast cancer. Am J Clin Nutr 1990; 52: 903-8.

6. Boyd NF, Stone J, Vogt KN, Connelly BS, Martin LJ, Minkin S. Dietary fat and breast cancer risk revisited: a meta-analysis of the published literature. Br J Cancer 2003; 89: 1672-85.

7. Velie E, Kulldorff M, Schairer C, Block G, Albanes D, Schatzkin A. Dietary fat, fat subtypes, and breast cancer in postmenopausal women: a prospective cohort study. J Natl Cancer Inst 2000; 92: 833-9.

8. Byrne C, Rockett H, Holmes MD. Dietary fat, fat subtypes, and breast cancer risk: lack of an association among postmenopausal women with no history of benign breast disease. Cancer Epidemiol Biomarkers Prev 2002; 11: 261-5.

9. Kim EH, Willett WC, Colditz GA, Hankinson SE, Stampfer MJ, Hunter DJ, Rosner B, Holmes MD. Dietary fat and risk of postmenopausal breast cancer in a 20-year follow-up. Am J Epidemiol 2006; 164: 990-7.

10. Lof M, Sandin S, Lagiou P, Hilakivi-Clarke L, Trichopoulos D, Adami HO, Weiderpass E. Dietary fat and breast cancer risk in the Swedish women's lifestyle and health cohort. Br J Cancer 2007; 97: 1570-6.

11. Sieri S, Krogh V, Ferrari P, et al. Dietary fat and breast cancer risk in the European Prospective Investigation into Cancer and Nutrition. Am J Clin Nutr 2008; 88: 1304-12.

12. Thiebaut AC, Chajes V, Gerber M, et al. Dietary intakes of omega- 6 and omega-3 polyunsaturated fatty acids and the risk of breast cancer. Int J Cancer 2009; 124: 924-31.

13. Sczaniecka AK, Brasky TM, Lampe JW, Patterson RE, White E. Dietary intake of specific fatty acids and breast cancer risk among postmenopausal women in the VITAL cohort. Nutr Cancer 2012; 64: 1131-42. 
14. Murff HJ, Shu XO, Li H, et al. Dietary polyunsaturated fatty acids and breast cancer risk in Chinese women: a prospective cohort study. Int J Cancer 2011; 128: 1434-41.

15. Rose DP. Effects of dietary fatty acids on breast and prostate cancers: evidence from in vitro experiments and animal studies. Am J Clin Nutr 1997; 66: 1513S-1522S.

16. Rose DP, Connolly JM, Coleman M. Effect of omega-3 fatty acids on the progression of metastases after the surgical excision of human breast cancer cell solid tumors growing in nude mice. Clin Cancer Res 1996; 2: 1751-6.

17. Hardman WE, Munoz J Jr, Cameron IL. Role of lipid peroxidation and antioxidant enzymes in omega 3 fatty acids induced suppression of breast cancer xenograft growth in mice. Cancer Cell Int 2002; 2: 10.

18. Welsch CW. Review of the effects of dietary fat on experimental mammary gland tumorigenesis: role of lipid peroxidation. Free Radic Biol Med 1995; 18: 757-73.

19. Sun H, Berquin IM, Edwards IJ. Omega-3 polyunsaturated fatty acids regulate syndecan-1 expression in human breast cancer cells. Cancer Res 2005;65:4442-7.

20. Zheng W, Gustafson DR, Sinha R, et al. Well-done meat intake and the risk of breast cancer. J Natl Cancer Inst 1998; 90: 1724-9.

21. Sinha R, Gustafson DR, Kulldorff M, Wen WQ, Cerhan JR, Zheng W. 2-amino-1-methyl-6-phenylimidazo[4,5-b]pyridine, a carcinogen in high-temperature-cooked meat, and breast cancer risk. J Natl Cancer Inst 2000; 92: 1352-4.

22. Delfino RJ, Sinha R, Smith C, et al. Breast cancer, heterocyclic aromatic amines from meat and $\mathrm{N}$-acetyltransferase 2 genotype. Carcinogenesis 2000; 21: 607-15.

23. Genkinger JM, Makambi KH, Palmer JR, Rosenberg L, Ad ams-Campbell LL. Consumption of dairy and meat in relation to breast cancer risk in the Black Women's Health Study. Cancer Causes Control 2013; 24: 675-84.

24. Larsson SC, Bergkvist L, Wolk A. Long-term meat intake and risk of breast cancer by oestrogen and progesterone receptor status in a cohort of Swedish women. Eur J Cancer 2009; 45: 3042-6.

25. Tao P, Li H, Wang Q, Cao LQ, Li JY, Yang F, Wang YP. A case-control study on association of SULT1A1 polymorphism, smoked meat intake with breast cancer risk. Zhonghua Yu Fang Yi Xue Za Zhi 2012; 46: 831-5.

26. FuZ, Deming SL, Fair AM, Shrubsole MJ, Wujcik DM, ShuXO, Kelley M Zheng $W$. Well-done meat intake and meat-derived mutagen exposures in relation to breast cancer risk: the Nashville Breast Health Study. Breast Cancer Res Treat 2011; 129: 919-28.

27. Dai Q, Shu XO, Jin F, Gao YT, Ruan ZX, Zheng W. Consumption of animal foods, cooking methods, and risk of breast cancer. Cancer Epidemiol Biomarkers Prev 2002; 11: 801-8.

28. Sinha R, Kulldorff M, Chow WH, Denobile J, Rothman N. Dietary intake of heterocyclic amines, meat-derived mutagenic activity, and risk of colorectal adenomas. Cancer Epidemiol Biomarkers Prev 2001; 10: 559-62.

29. Knize MG, Felton JS. Formation and human risk of carcinogenic heterocyclic amines formed from natural precursors in meat. Nutr Rev 2005; 63: 158-65

30. Felton JS, Knize MG, Wu RW, Colvin ME, Hatch FT, Malfatti MA Mutagenic potency of food-derived heterocyclic amines. Mutat Res 2007; 616: 90-4.

31. Snyderwine EG, Venugopal M, Yu M. Mammary gland carcinogenesis by food-derived heterocyclic amines and studies on the mechanisms of carcinogenesis of 2-amino-1-methyl-6-phenylimidazo[4,5-b]pyridine (PhIP). Mutat Res 2002; 506-507: 145-52.

32. Zhang S, Hunter DJ, Hankinson SE, Giovannucci EL, Rosner BA, Colditz GA, Speizer FE, Willett WC. A prospective study of folate intake and the risk of breast cancer. JAMA 1999; 281: 1632-7.

33. Zheng W, Xie D, Cerhan JR, Sellers TA, Wen W, Folsom AR. Sulfotransferase $1 \mathrm{~A} 1$ polymorphism, endogenous estrogen exposure, well-done meat intake, and breast cancer risk. Cancer Epidemiol Biomarkers Prev 2001; 10: 89-94.

34. Zheng W, Wen WQ, Gustafson DR, Gross M, Cerhan JR, Folsom AR. GSTM1 and GSTT1 polymorphisms and postmenopausal breast cancer risk. Breast Cancer Res Treat 2002; 74: 9-16.

35. Deitz AC, Zheng W, Leff MA, et al. N-Acetyltransferase-2 genetic polymorphism, well-done meat intake, and breast cancer risk among postmenopausal women. Cancer Epidemiol Biomarkers Prev 2000; 9: 905-10.

36. Terry $P$, Jain M, Miller AB, Howe GR, Rohan TE. No association among total dietary fiber, fiber fractions, and risk of breast cancer. Cancer Epidemiol Biomarkers Prev 2002; 11: 1507-8.

37. Cho E, Spiegelman D, Hunter DJ, Chen WY, Colditz GA, Willett WC. Premenopausal dietary carbohydrate, glycemic index, glycemic load, and fiber in relation to risk of breast cancer. Cancer Epidemiol Biomarkers Prev 2003; 12: 1153-8.

38. Holmes MD, Liu S, Hankinson SE, Colditz GA, Hunter DJ, Willett WC. Dietary carbohydrates, fiber, and breast cancer risk. Am J Epidemiol 2004; 159: 732-9.

39. Cade JE, Burley VJ, Greenwood DC. Dietary fibre and risk of breast cancer in the UK Women's Cohort Study. Int J Epidemiol 2007; 36: 431-8.

40. Park Y, Brinton LA, Subar AF, Hollenbeck A, Schatzkin A. Dietary fiber intake and risk of breast cancer in postmenopausal women: the National Institutes of Health-AARP Diet and Health Study. Am I Clin Nutr 2009; 90: 664-71.

41. Mattisson I, WirfaltE, Johansson U, Gullberg B, Olsson H, Berglund G. Intakes of plant foods, fibre and fat and risk of breast cancer a prospective study in the Malmo Diet and Cancer cohort. $\mathrm{Br}$ J Cancer 2004; 90: 122-7.

42. Dong JY, He K, Wang P, Qin LQ. Dietary fiber intake and risk of breast cancer: a meta-analysis of prospective cohort studies. Am J Clin Nutr 2011; 94: 900-5.

43. Fung TT, Chiuve SE, Willett WC, Hankinson SE, Hu FB, Holmes MD. Intake of specific fruits and vegetables in relation to risk of estrogen receptor-negative breast cancer among postmenopausal women. Breast Cancer Res Treat 2013.

44. Touillaud MS, Thiebaut AC, Fournier A, Niravong M, Boutron-Ruault MC, Clavel-Chapelon F. Dietary lignan intake and postmenopausal breast cancer risk by estrogen and progesterone receptor status. J Natl Cancer Inst 2007; 99: 475-86.

45. Moore MA, Park CB, Tsuda H. Soluble and insoluble fiber influences on cancer development. Crit Rev Oncol Hematol 1998; 27 : 229-42.

46. Hanf V, Gonder U. Nutrition and primary prevention of breast cancer: foods, nutrients and breast cancer risk. Eur J Obstet Gynecol Reprod Biol 2005; 123: 139-49.

47. Rohan TE, Jain M, Howe GR, Miller AB. Alcohol consumption and risk of breast cancer: a cohort study. Cancer Causes Control 2000; 11: 239-47.

48. Poschl G, Stickel F, Wang XD, Seitz HK. Alcohol and cancer: genetic and nutritional aspects. Proc Nutr Soc 2004; 63: 65-71.

49. Singletary KW, Gapstur SM. Alcohol and breast cancer: review of epidemiologic and experimental evidence and potential mechanisms. JAMA 2001; 286: 2143-51.

50. Smith-Warner SA, Spiegelman D, Yaun SS, et al. Alcohol and breast cancer in women: a pooled analysis of cohort studies. JAMA 1998; 279: 535-40

51. Hamajima N, Hirose K, Tajima K, et al. Alcohol, tobacco and breast cancer - collaborative reanalysis of individual data from 53 epidemiological studies, including 58,515 women with breast cancer and 95,067 women without the disease. Br J Cancer 2002; 87: 1234-45.

52. Coronado GD, Beasley J, Livaudais J. Alcohol consumption and the risk of breast cancer. Salud Publica Mex 2011; 53: 440-7.

53. Dorgan JF, Baer DJ, Albert PS, et al. Serum hormones and the alcohol-breast cancer association in postmenopausal women. J Natl Cancer Inst 2001; 93: 710-5.

54. Dumitrescu RG, Cotarla I. Understanding breast cancer risk where do we stand in 2005? I Cell Mol Med 2005; 9: 208-21.

55. Garro AJ, Lieber CS. Alcohol and cancer. Annu Rev Pharmacol Toxicol 1990; 30: 219-49.

56. Homann N, Jousimies-Somer H, Jokelainen K, Heine R, Salaspuro M. High acetaldehyde levels in saliva after ethanol consumption: methodological aspects and pathogenetic implications. Carcinogenesis 1997; 18: 1739-43.

57. Peeters PH, Keinan-Boker L, van der Schouw YT, Grobbee DE. Phytoestrogens and breast cancer risk. Review of the epidemiological evidence. Breast Cancer Res Treat 2003; 77: 171-83. 
58. Dong JY, Qin LQ. Soy isoflavones consumption and risk of breast cancer incidence or recurrence: a meta-analysis of prospective studies. Breast Cancer Res Treat 2011; 125: 315-23.

59. Xie Q, Chen ML, Qin Y, et al. Isoflavone consumption and risk of breast cancer: a dose-response meta-analysis of observational studies. Asia Pac J Clin Nutr 2013; 22: 118-27.

60. Trock BJ, Hilakivi-Clarke L, Clarke R. Meta-analysis of soy intake and breast cancer risk. J Natl Cancer Inst 2006; 98: 459-71.

61. Hui C, Qi X, Qianyong Z, Xiaoli P, Jundong Z, Mantian M. Flavonoids, flavonoid subclasses and breast cancer risk: a meta-analysis of epidemiologic studies. PLoS One 2013; 8: e54318.

62. Brzezinski A, Debi A. Phytoestrogens: the "natural" selective es trogen receptor modulators? Eur J Obstet Gynecol Reprod Biol 1999; 85: 47-51.

63. Riggs BL, Hartmann LC. Selective estrogen-receptor modulators -mechanisms of action and application to clinical practice. N Engl Med 2003; 348: 618-29.

64. Gruber CJ, Tschugguel W, Schneeberger C, Huber JC. Production and actions of estrogens. N Engl J Med 2002; 346: 340-52.

65. Anderson JJ, Anthony M, Messina M, Garne SC. Effects of phyto-oestrogens on tissues. Nutr Res Rev 1999; 12: 75-116.

66. Adlercreutz $\mathrm{H}$. Evolution, nutrition, intestinal microflora, and prevention of cancer: a hypothesis. Proc Soc Exp Biol Med 1998; 217: 241-6.

67. Kurzer MS, Xu X. Dietary phytoestrogens. Annu Rev Nutr 1997; 17: 353-81.

68. Rice S, Whitehead SA. Phytoestrogens oestrogen synthesis and breast cancer. J Steroid Biochem Mol Biol 2008; 108: 186-95.

69. Ooi LL, Zhou H, Kalak R, Zheng Y, Conigrave AD, Seibel MJ, Dunstan CR. Vitamin D deficiency promotes human breast cance growth in a murine model of bone metastasis. Cancer Res 2010; 70: $1835-44$

70. Colston KW, Hansen CM. Mechanisms implicated in the growth regulatory effects of vitamin $D$ in breast cancer. Endocr Relat Cancer 2002; 9: 45-59.

71. Koli K, Keski-Oja J. 1alpha,25-dihydroxyvitamin D3 and its analogues down-regulate cell invasion-associated proteases in cultured malignant cells. Cell Growth Differ 2000; 11: 221-9.

72. Abbas S, Chang-Claude J, Linseisen J. Plasma 25-hydroxyvitamin D and premenopausal breast cancer risk in a German case-control study. Int J Cancer 2009; 124: 250-5.

73. Garland CF, Gorham ED, Mohr SB, et al. Vitamin D and prevention of breast cancer: pooled analysis. J Steroid Biochem Mol Biol 2007; 103: 708-11.

74. Chen P, Li M, Gu X, et al. Higher blood 25(OH)D level may reduce the breast cancer risk: evidence from a Chinese population based case-control study and meta-analysis of the observational studies. PLoS One 2013; 8: e49312.

75. Kuhn T, Kaaks R, Becker S, et al. Plasma 25(OH)vitamin D and the risk of breast cancer in the european prospective investigation into cancer and nutrition (EPIC): A nested case-control study. Int Cancer 2013; 133: 1689-700.

76. Scarmo S, Afanasyeva Y, Lenner P, et al. Circulating levels of 25-hydroxyvitamin D and risk of breast cancer: a nested case-control study. Breast Cancer Res 2013; 15: R15.

77. Abbas S, Linseisen J, Rohrmann S, et al. Dietary intake of vitamin d and calcium and breast cancer risk in the European prospective in vestigation into cancer and nutrition. Nutr Cancer 2013; 65: 178-87.

78. Yao S, Ambrosone CB. Associations between vitamin D deficiency and risk of aggressive breast cancer in African-American women. J Steroid Biochem Mol Biol 2012.

79. Chen WY, Bertone-Johnson ER, Hunter DJ, Willett WC, Hankinson SE. Associations between polymorphisms in the vitamin D recepto and breast cancer risk. Cancer Epidemiol Biomarkers Prev 2005; 14: $2335-9$

80. Guy M, Lowe LC, Bretherton-Watt D, et al. Vitamin D receptor gene polymorphisms and breast cancer risk. Clin Cancer Res 2004; 10 5472-81.

81. Abbas S, Linseisen J, Slanger T, Kropp S, Mutschelknauss EJ, Flesch-Janys D, Chang-Claude J. The Gc2 allele of the vitamin D binding protein is associated with a decreased postmenopausa breast cancer risk, independent of the vitamin D status. Cancer Epidemiol Biomarkers Prev 2008; 17: 1339-43.
82. Jensen SS, Madsen MW, Lukas J, Binderup L, Bartek J. Inhibitory effects of 1alpha,25-dihydroxyvitamin $\mathrm{D}(3)$ on the $\mathrm{G}(1)-\mathrm{S}$ phase-controlling machinery. Mol Endocrinol 2001; 15: 1370-80.

83. Simboli-Campbell M, Narvaez CJ, van Weelden K, Tenniswood M, Welsh J. Comparative effects of 1,25(OH)2D3 and EB1089 on cell cycle kinetics and apoptosis in MCF-7 breast cancer cells. Breast Cancer Res Treat 1997; 42: 31-41.

84. James SY, Mackay AG, Colston KW. Effects of 1,25 dihydroxyvitamin D3 and its analogues on induction of apoptosis in breast cancer cells. J Steroid Biochem Mol Biol 1996; 58: 395-401.

85. Krishnan AV, Swami S, Peng L, Wang J, Moreno J, Feldman D. Tis sue-selective regulation of aromatase expression by calcitriol: implications for breast cancer therapy. Endocrinology 2010; 151: 32-42.

86. Fleming DJ, Jacques PF, Tucker KL, Massaro JM, D’Agostino RB Sr, Wilson PW, Wood RJ. Iron status of the free-living, elderly Framingham Heart Study cohort: an iron-replete population with a high prevalence of elevated iron stores. Am J Clin Nutr 2001; 73: 638-46.

87. Liu JM, Hankinson SE, Stampfer MJ, Rifai N, Willett WC, Ma J. Body iron stores and their determinants in healthy postmenopausal US women. Am J Clin Nutr 2003; 78: 1160-7.

88. Stevens RG, Jones DY, Micozzi MS, Taylor PR. Body iron stores and the risk of cancer. N Engl J Med 1988; 319: 1047-52.

89. Stevens RG, Graubard BI, Micozzi MS, Neriishi K, Blumberg BS. Moderate elevation of body iron level and increased risk of cancer occurrence and death. Int J Cancer 1994; 56: 364-9.

90. Siegers CP, Bumann D, Baretton G, Younes M. Dietary iron enhances the tumor rate in dimethylhydrazine-induced colon carcinogenesis in mice. Cancer Lett 1988; 41: 251-6.

91. Smith AG, Francis JE, Carthew P. Iron as a synergist for hepatocellular carcinoma induced by polychlorinated biphenyls in Ah-responsive C57BL/10ScSn mice. Carcinogenesis 1990; 11: 437-44.

92. Hann HW, Stahlhut MW, Blumberg BS. Iron nutrition and tumor growth: decreased tumor growth in iron-deficient mice. Cancer Res 1988; 48: 4168-70.

93. Hann HW, Stahlhut MW, Menduke H. Iron enhances tumor growth. Observation on spontaneous mammary tumors in mice. Cancer 1991; 68: 2407-10.

94. Huang X. Iron overload and its association with cancer risk in humans: evidence for iron as a carcinogenic metal. Mutat Res 2003; 533: 153-71.

95. McCord JM. Iron, free radicals, and oxidative injury. Semin $\mathrm{He}$ matol 1998; 35: 5-12.

96. Toyokuni S. Iron-induced carcinogenesis: the role of redox regulation. Free Radic Biol Med 1996; 20: 553-66.

97. Pinnix ZK, Miller LD, Wang W, et al. Ferroportin and iron regulation in breast cancer progression and prognosis. Sci Transl Med 2010; 2: 43ra56.

98. Nemeth E, Tuttle MS, Powelson J, Vaughn MB, Donovan A, Ward DM, Ganz T, Kaplan J. Hepcidin regulates cellular iron efflux by binding to ferroportin and inducing its internalization. Science 2004; 306: 2090-3.

99. Freudenheim JL, Marshall JR, Vena JE, Laughlin R, Brasure JR, Swanson MK, Nemoto T, Graham S. Premenopausal breast cancer risk and intake of vegetables, fruits, and related nutrients. Jatl Cancer Inst 1996; 88: 340-8.

100. Potischman N, Swanson CA, Coates RJ, Gammon MD, Brogan DR, Curtin J, Brinton LA. Intake of food groups and associated micronutrients in relation to risk of early-stage breast cancer. Int J Cancer 1999; 82: 315-21.

101. Rohan TE, Jain MG, Howe GR, Miller AB. Dietary folate consumption and breast cancer risk. J Natl Cancer Inst 2000; 92: 266-9.

102. Shrubsole MJ, Jin F, Dai Q, Shu XO, Potter JD, Hebert JR, Gao YT, Zheng $W$. Dietary folate intake and breast cancer risk: results from the Shanghai Breast Cancer Study. Cancer Res 2001; 61: 7136-41.

103. Islam T, Ito $H$, Sueta $A$, et al. Alcohol and dietary folate intake and the risk of breast cancer: a case-control study in Japan. Eur J Cancer Prev 2013; 22: 358-66.

104. Yang D, Baumgartner RN, Slattery ML, et al. Dietary intake of folate, B-vitamins and methionine and breast cancer risk among 
Hispanic and non-Hispanic white women. PLoS One 2013; 8: e54495.

105. Ericson U, Sonestedt E, Gullberg B, Olsson H, Wirfalt E. High folate intake is associated with lower breast cancer incidence in postmenopausal women in the Malmo Diet and Cancer cohort. Am J Clin Nutr 2007; 86: 434-43.

106. Stevens VL, McCullough ML, Sun J, Gapstur SM. Folate and other one-carbon metabolism-related nutrients and risk of postmenopausal breast cancer in the Cancer Prevention Study II Nutrition Cohort. Am J Clin Nutr 2010; 91: 1708-15.

107. Maruti SS, Ulrich CM, White E. Folate and one-carbon metabolism nutrients from supplements and diet in relation to breast cancer risk. Am J Clin Nutr 2009; 89: 624-33.

108. Stolzenberg-Solomon RZ, Chang SC, Leitzmann MF, Johnson KA, Johnson C, Buys SS, Hoover RN, Ziegler RG. Folate intake, alcohol use, and postmenopausal breast cancer risk in the Prostate, Lung, Colorectal, and Ovarian Cancer Screening Trial. Am J Clin Nutr 2006; 83: 895-904.

109. Kim YI. Folate and colorectal cancer: an evidence-based critical review. Mol Nutr Food Res 2007; 51: 267-92.

110. Claus EB, Risch NJ, Thompson WD. Age at onset as an indicator of familial risk of breast cancer. Am J Epidemiol 1990; 131: $961-72$.

111. Hankinson SE, Colditz GA, Willett WC. Towards an integrated model for breast cancer etiology: the lifelong interplay of genes, lifestyle, and hormones. Breast Cancer Res 2004; 6: 213-8.

112. Familial breast cancer: collaborative reanalysis of individual data from 52 epidemiological studies including 58,209 women with breast cancer and 101,986 women without the disease. Lancet 2001; 358: 1389-99.

113. Metcalfe KA, Finch A, Poll A, et al. Breast cancer risks in women with a family history of breast or ovarian cancer who have tested negative for a BRCA1 or BRCA2 mutation. Br J Cancer 2009; 100: 421-5.

\section{Address for correspondence}

\section{Manas Kotepui}

Medical Technology Program

School of Allied Health Sciences and Public Health

Walailak University

Nakhon Si Thammarat, 80161, Thailand

tel. 66860390260

fax: 6675672106

e-mail: manas.ko@wu.ac.th

Submitted: 15.05 .2013

Accepted: 8.11.2013 